\title{
“I'VE HAD TOO MUCH DONE TO MY HEART": THE DILEMMA OF ADDICTION AND RECOVERY AS SEEN THROUGH SEVEN YOUNGSTERS' LIVES
}

\author{
WELSEY LONG \\ COURTNEY VAUGHN \\ University of Oklahoma
}

\begin{abstract}
Aware of the dearth of in-depth studies on recovering adolescent addict/ alcoholics, we conducted a year-long qualitative study of seven formerly-addicted youth committed to recovery. The research question was: how do addicted youth become and remain sober? Bending to social stress, including racism and ethnic prejudice, three participants relapsed. However, personal commitment augmented by familial, community, spiritual, and educational support encouraged four to remain sober. Learning from both those who failed and succeeded, the theoretical concepts of surrender, social stress, and resiliency helped to interpret the participants' patterns of response and better understand adolescent recovery.
\end{abstract}

Investigating the topic of drug and alcohol addiction among adolescents in the United States can be a depressing business. As one young woman so prophetically told us, "I've had too much done to my heart." Most of these youngsters either drop out or are expelled from school and end up in prisons, mental hospitals, or treatment centers. But few recover while they are still young, if ever at all. Perhaps in search of hope and aware of the few in-depth studies of recovering adolescent addict/alcoholics, we conducted a longitudinal qualitative study of seven formerly-addicted youth committed to recovery [1-4].

\section{DESIGN}

After spending many hours with the residents, teachers, counselors, and administrators of a nationally acclaimed residential school and long-term treatment center for addicted youth, we selected seven teenage participants 
who seemed highly committed to changing their lives: two Euro-American males; one African- and one Jordanian-American male; two Euro-American females; and one American-Indian female. Patients are released, usually after several months, when the center's staff believes they have a relatively decent environment in which to live and a chance to live sober and productive lives. The program stresses the Twelve Steps of Alcoholics Anonymous (AA) which emphasize cultivation of a spiritual life and rigorous self assessment, resulting in changing past destructive behavior and living a "golden rule" existence. (For the Twelve Steps of AA, see Appendix A.)

We conducted an ethnographic-phenomenological investigation into the experiences of these youngsters, in particular their prior existence in a drug- and alcohol-infested world, demises, and subsequent struggles to change. First, we conducted extensive phenomenological interviews with each one, generating a life history and extensive responses to questions relating to their efforts to become and remain sober [5-7]. Throughout a twelve-month period we conducted several more interviews with each youngster, occurring both before and after being released from treatment. Creating an ethnographic element to the study we spent hours socializing with and observing the participants at the treatment center and conducting interviews with various counselors, teachers, and family members to determine the trustworthiness of the participants' stories [8].

After having transcribed, coded, and patterned the data, we found that the life of each participant was similar and yet unique [8]. Two distinct groups existed: three relapsed while four remained clean and sober. The experience of the participants making up each of these categories produced thematic responses to the research question: how do addicted youth become and remain sober? They emerge by implication in the following individual portraits and are identified and interpreted in the next section.

\section{THREE RELAPSE}

\section{Melinda}

Melinda was fifteen years old when we first met her. Her mother was a full-blood Navajo who never knew her own parents. The older woman spent much of her childhood in foster homes and orphanages, and during this time experienced sexual abuse. Eventually, she was adopted by a white family. Melinda's mother was never married to her estranged father, an alcoholic of mixed racial ancestry: Cherokee, German, Filipino, and Guatemalan. Currently, he is living in Guam with a wife and children.

When Melinda was ten, her mother married a man who became Melinda's adoptive father. The couple had one other child, a boy several years younger than Melinda; but they divorced a few years after his birth. Her adoptive father 
is a recovering alcoholic and attends numerous AA meetings. Her mother drinks only occasionally but is addicted to over-the-counter mini-thins. During our study Melinda's mother was very depressed; she had not held down a full-time job since her divorce. Melinda's mother was emotionally homebound, remaining in her room as much as possible and relying on Melinda's grandmother for financial support. When at home Melinda provided all the nurturing needs for her younger brother, as it was not uncommon for her mother to go for days without speaking. "She said she couldn't handle us kids," Melinda told us, "and her solution was just to go to her room and not to look at it." Melinda desperately "wanted them [Melinda's mother and stepfather] back together because it really hurt and everything because I missed my dad, and it wasn't the same."

Melinda was a good student until her mother and stepfathers' divorce. At thirteen, she started using drugs and alcohol to be accepted by her peers and to make her problems "go away." As a user, Melinda experienced blackouts, ran away from home, and was involved in delinquent behavior. Eventually, her mother banished her from the house, and her adoptive father forced her into treatment.

There, Melinda seemed to accept the discipline and demands of schoolwork and recovery. Yet, her mother rarely came to see her, and Melinda suspected that "she [only] wants me back home for cleaning." Melinda begged her adoptive father to take her after she completed the program. $\mathrm{He}$ refused.

Feeling that she had no hope for a loving home, after many months of treatment, Melinda ran away and was never found. Melinda's father said she called her brother several times and then was never heard from again. The authorities believe she may be dead.

Ali

When we first met Ali he was seventeen years old. Born in Jordan, when Ali was four, he, his four siblings, and his parents had moved to the United States where they became financially successful. Although his parents were Christian, they were also traditionally Middle Eastern, stressing the importance of the extended family and deference to familial male authority figures.

In school Ali excelled until his encounter with drugs in the ninth grade. He started using marijuana and nicotine, as do so many youth, but it was not long before he experimented with acid, cocaine, crank, crystal methane, and crack cocaine. He began stealing money and salable goods to buy drugs. He even robbed his uncle's and parents' homes. He was caught, tried, and sentenced to drug treatment.

When attempting to explain why he began using, he recalled that certain students routinely called him ethnic names such as "camel jockey." 
No one noticed me. I was a good wrestler and didn't get any attention from that. Our school was big on wrestling, and I thought this would make me more popular. When a guy who was kicked off the wrestling team invited me to his house I thought this was the beginning for me. All they did was get high, and before long I was getting high with them.

Ali was quite productive and successful in treatment. Yet his family was filled with shame and visited him only sporadically. After leaving treatment it appeared as though Ali was in recovery. He continued to attend AA meetings and work toward a GED. However, he was refused entrance back into public school. Perhaps to ease the blow, his parents bought him an expensive new car, and he was soon a noticeable target for the opportunistic people who have been known to attend Twelve Step meetings. He was approached by two white females who asked for a ride home. Ali consented, only to discover the women were drug dealers. Ali smoked crack two weeks after becoming involved with them and was selling drugs the next week. He was caught and sentenced to serve time in a penitentiary. Now released, he is again using and selling drugs.

\section{Anthony}

When we first met Anthony, an African-American, he was eighteen years old. His father and mother were no longer together, and he was not certain if they were ever married. Apparently, however, his father and mother had provided for themselves and five children, but that had all ended when his parents severed their relationship. Then ten years old, Anthony, his mother, and the children moved into a low income housing project, and Anthony's life changed dramatically.

Anthony's mother became addicted to drugs and he was surrounded by numerous other youngsters who engaged in delinquent behavior. He began drinking and using marijuana and other drugs, as did the other children living in his mother's home. Perhaps in search of another family, Anthony also joined a gang.

Amazingly, Anthony did attend public school until he reached the tenth grade, but, as he put it. "I wasn't getting anything from school but high." At seventeen he was court ordered to treatment as a result of drugand alcohol-related felony convictions.

While in treatment Anthony worked toward completing his high school diploma, and his counselors believed that he showed signs of authentic recovery. After leaving the center, the pressure to provide money for his family, ironically, the lack of family support, and his own needs to appear successful drove him back to dealing drugs. He was arrested and fled prosecution after being released on bail. Today, he has been recaptured, tried and convicted and, at the time of this writing, is in prison. 


\section{FOUR REMAIN SOBER}

\section{Jessica}

Jessica was sixteen when our study began. A Euro-American female, she was one of two children born to her mother and father. Her mother worked in a bank and her biological father, who is now deceased, was an oil field worker. An alcoholic, he had spent time in the penitentiary for numerous drunk driving convictions and eventually died of a heart attack, most probably brought on by excessive drinking. Jessica was only eleven at the time. Probably, financial destitution led Jessica's mother to remarry. That relationship was not successful, and the couple separated when Jessica was eleven.

The death of Jessica's father and the introduction of her mother's new husband and his three children into their household had a disastrous affect on her already fragile state. She fought regularly with her stepbrother who tried to kill her on one occasion. One night he reached for a gun which he thought was loaded and pointed it to "my head and pulled the trigger, and there weren't any bullets in it."

Incidences such as these characterized Jessica's fall into oblivion. Jessica had already begun to drink when she was ten. She added marijuana, crank, cocaine, crack cocaine, acid, ecstasy, PCP, and crystal methane to the list. More dramatic than her drug and alcohol use was that she "never paid for it. The only thing I've ever bought was a six-pack of beer." One night Jessica overdosed and was taken to a hospital. She had been found in a hotel room with eight adult men who were arrested for drinking and having sex with a minor.

Jessica was sent to treatment for the third time, where she did well. After graduation from the facility Jessica moved in with her mother who insisted to local school officials that Jessica be re-admitted to high school. Moreover, Jessica's mother drove her fifty miles to attend support group meetings. Grateful, Jessica told us:

I don't know what I would do without my mother. We used to have so many fights and problems. She told me she loved me, and she wanted me to stop using drugs. . . . My mother works at the bank and every one in town knows her. She told my teacher that I would be glad to talk about drugs and how they almost ruined my life. It's kind of funny that I speak to students every two weeks about staying away from drugs.

Jessica was proud that she was asked to provide drug education for her school. "I was scared at first but so many of those people didn't know the first thing about drugs. In rural towns people mostly drink. It was amazing to hear myself trying to talk people out of trying drugs. These group meetings were kind of like A.A. for me." 
As the months wore on, Jessica's popularity increased not only with her peers but with parents in the town. Jessica was singled out at a school assembly by the principal and her homeroom teacher for her work with drug education. Jessica was surprised by the recognition and was even more gratified when the principal announced that the school almost refused to re-enroll her. "I think my assisting in the drug groups helped me. Even if I wanted to get high . . . I don't. I would disappoint so many people. People look up to me, and I couldn't do that to them."

\section{John}

Characterized as nobody's child, John, a Euro-American, was eighteen years old when we first interviewed him. His mother, who had two children, died when John was six, and he was sent to live with a grandfather. His grandfather died shortly thereafter, and an aunt took him in. After a short stay, John was shuffled off to his grandmother' house. She became ill and a neighbor, Jake, took John in and became his legal guardian.

The instability of John's life and the availability of drugs led him into early delinquent activities. As a preteen John began using marijuana, and at thirteen John was participating in gang-related felonious acts. Eventually, he was arrested for destruction of property, assault and battery, theft, and petty larceny and sentenced to a drug treatment program. John's guardian supported him through these and other arrests and two treatment center stints. "I was involved with gangs, guns, and drugs all while I'm staying in his home, and he was patient with me, never pressuring me. He asked me if I wanted help with my drug use. If needed he would get me into treatment or counseling." John believed that God sent this father figure to him.

John admitted that he turned his life around while in drug treatment. But he believed that any positive focus, such as religious convictions or pursuance of a college degree, could insure sobriety and a productive life; for example, he did not think that regularly attending Twelve Step meetings, as stressed in treatment, was the only means of remaining sober. According to John, young people such as he "involve themselves in gangs [and drugs] because of the sense of security that is involved in it and the sense of love that they feel from other people. They probably haven't gotten it in any of their life." For John, replacing the emptiness with devout religious convictions has keep him focused and sober.

John was proud that he graduated from the treatment program in six months, faster than anyone before him. But he was also quick to give most of the credit to God. John had taken high school courses while in treatment and, after leaving, returned to public school. After graduating John enrolled in a nearby community college. His career interests included physical therapy and the ministry. In college, John met a fellow student to whom he later proposed. The wedding was canceled when John's fiancee became pregnant by another man. John dropped out of school, stopped attending church (but was still a devout Christian), and quit his full-time job. He became a door-to-door vacuum cleaner 
salesman for a while and, at the time of this writing, is seeking other employment.

\section{Mick}

Mick was eighteen years old when we began our study. A Euro-American male, he was the younger of two boys born to working class parents. Mick grew up in a violent home. He father regularly beat the boys and their mother. Mick sadly remembered, "we didn't know what he was going to be like when he came in, ... if he was going to flip out about what happened at work today, or if he was going to bring some candy to us." The couple divorced when Mick was twelve.

Mick's family also has a history of alcohol and drug abuse. His maternal aunt and grandfather were alcoholics; while his father was a heavy drinker and smoked marijuana. With his older brother, Mick started experimenting with drugs at the age of twelve, smoking pot which they obtained from their father's "stash." By the time Mick was sixteen he was addicted to crack cocaine and involved with gangs. From the seventh to tenth grades Mick was a terrible student. Yet, a part of him always wanted to do well. He repeated the tenth grade three times before deciding to quit. Soon after, he was arrested for grand larceny and sentenced to drug treatment.

Also following a somewhat non-traditional path, after a short stint Mick was discharged from the treatment center for not following facility rules. But instead of being placed back into the streets, the facility allowed him to enroll in the adult inpatient program. Mick was grateful because he was still on probation for robbery, breaking and entering, and drug possession, and total suspension from the facility would have forced him back into court where he could have been sentenced as an adult to time in a penitentiary. Encouraged by a few older men serious about recovery, while in the adult center Mick diligently worked the Twelve Steps and attempted to find employment.

After leaving treatment Mick attributed his success to the fear of going to prison (which was imminent if he continued using) and his dedication to the A.A. program. Also, following a suggestion from his parole officer, Mick enrolled in a local junior college. Proud of himself, he told us, "I get pumped about going to school. I love that, man. I love being able to say, 'hey, I'm going to college. ... I go to work' . . makes me feel good to be productive and have an organized lifestyle."

For the first time in his life Mick believed he had a future. "I pray every day that I won't ever use again. I no longer crave drugs or alcohol. There was a time if I smelled drugs it took all I had to stop from trying to get some. Prayer has taken that away from me. I think I've beat my addiction but I got to keep going to meetings." Accompanying Mick from time to time is a newfound woman friend. Time will tell whether, as in John's case, the relationship will threaten or strengthen Mick's new sober life. 


\section{Lisa}

When we first interviewed Lisa, a Euro-American female, she was sixteen years old. She was the oldest of three girls. Her two younger sisters had also been involved with drugs. Their mother and father were no longer together. They divorced when Lisa was eleven. Both of her parents used heroine intravenously throughout her childhood. Her father was a violent man, physically abusing her mother. She and the two girls would move to a battered woman's shelter when the beatings became too regular or severe. Lisa's father and mother finally quit using after being arrested, convicted, and sent to prison for selling drugs.

During her short life, Lisa had been raped and involved with gangs; also, she has had three abortions. She was first raped by her father's best friend while her supposed protector lay comatose in the next room from a near heroine overdose. Eventually, the state took Lisa and her sister into protective custody and placed them in foster homes. Lisa remembered growing up in poor neighborhoods and attending public schools most of her academic years. She attended a private, religious school for a time, but even this restrictive environment could not protect her from herself. At eleven, Lisa had started using when she sniffed gasoline while walking home from school. Five years later she was committed to treatment after a near heroine overdose.

After Lisa completed the treatment center program she choose to live in a half-way house. Lisa was afraid to move in with her mother or father, both of whom had been released from prison. Lisa worked hard to develop a positive self image and eventually told us, "For the first time in my life I actually love myself, ... and no one is ever going to use me again. I won't let them." Then out of prison, her father attended a half-way house family group session, and Lisa told him, "'Your drug addiction almost killed you and Momma. You never considered me and Jill [her sister]. We went from foster home to foster home, and you never tried to change and come get us. I forgive you but I would never do my kids like you done us." Lisa and her father seemed to come to an understanding. Eventually, Lisa and her entire family began attending A.A. and N.A. meetings.

In addition, Lisa returned to school, although while in treatment she had taken and passed the GED exam. She went out for and made the girls' softball and volleyball teams. "I never attended school, and I wanted to prove to myself that I could be successful and graduate from high school." Also a pep club member, Lisa enjoyed being a student and making friends. For once she felt like a "normal" girl. "If these people knew of my past they would die. I'm doing so well no one knows I go to A.A. and N.A. meetings, or that I am in recovery. . . . For the first time I feel so normal. I was so crazy to use drugs. I almost ruined my life."

During the last few weeks of the study Lisa experienced the urge to use. She quit attending public school, got a job, and moved back into a half-way 
house, where her father was also living. Although Lisa had enjoyed school immensely, the pressure of appearing but not feeling normal and the easy access to drugs wore her down. "Passing" may have helped her stay sober, but it seemed to have accentuated, not ameliorated, Lisa's divided self [9].

\section{PATTERNS OF RESPONSE}

\section{Race and Ethnicity: Acceptance versus Nonacceptance}

The three participants who relapsed shared similar situations and characteristics that made sobriety difficult. All three were non-white, which hindered their being socially accepted whether they used or not. Ali had frequently been called "sand nigger" at school; and his subsequent need to be validated by whites led him to "start buying drugs and giving them away so that students would like me." Similarly his need to be associated with beautiful white girls led him back to using. After being arrested the last time Ali lamented, "I feel so stupid. I should have known that a woman in her thirties wouldn't want a man not even twenty. She needed someone with a car. Access to money, and crazy enough to supply her needs."

Like Ali, Melinda wanted the approval and acceptance of her peers. She had attended a suburban school with few non-white students. A small number of American Indians were enrolled in Melinda's school, but they wore long hair, occasionally dressed in a manner that indicated their culture and heritage, and were involved with their tribes' ceremonies and other activities. Melinda did not identify with them because she was reared "like a Caucasian." Culturally, Melinda had difficulty deciding where she belonged. Her adopted father was white, her mother was a fair-skinned American Indian, and her biological father had a mixed non-white ancestry. "It was hard making and keeping friends, and I thought and still do that a lot of it had to do with my race." When one of Melinda's few close friends began socializing with other students, Melinda became afraid that she would lose her friendship. The new friend was a year older than Melinda and was already using drugs and alcohol, mainly beer and marijuana. Melinda remembered, "At first I was afraid to use, but they started teasing me and calling me names, and I felt I had to ... I thought they would stop being my friends."

Also focusing on race, Anthony attributed being African American and poor to his entry into drug use. He spoke about how difficult it was for blacks to find decent employment and how the school district so easily gave up on him. "I went to school one day and the principal told me in his office that he felt I was causing problems for student and staff." The principal then informed him he would be going to school half a day three days a week, and he would not return until his office contracted his mother. One month later the call had never come. "If I was 
white there is no way this would have happened. Because I'm black they treat me any kind of way." Anthony never went back to school until he was forced into the drug treatment school. There, he seemed eager to continue his education. Nevertheless, after his release, he was bitter and frustrated. "When you're not high white people think you are; when you're not stealing, white people think you are; when you're looking for work, white people think you ain't." When reflecting on Anthony's words, he may have been saying, "I'll never make it."

The white students, on the other hand, seemed better able to blend back into their communities. Jessica flourished at her public school and was even accepted as a reformed user. Somewhat different from Jessica, Lisa feared exposure, telling us, "I thought there would be problems when I returned to school. I thought people would remember me. It had been a year and a half since I went there. Nobody noticed me. I guess it's because I looked like every other kid at school." Her ability to hide her past addiction and appear normal, white, and middle class, for a time enabled her to work on her recovery without setbacks.

Mick and John had no problems resuming their school lives when they returned to their communities. Mick's probation officer even helped him enroll. "It was easier than I thought. I don't think no one remembered me. . . . Everyone I used to get high with got kicked out, dropped out, or graduated. I picked up where I left off when I used to go there. Hanging in the halls, meeting with babes, and hanging out on weekends." Public education also welcomed John back.

They didn't ask any questions. I went with my transcript from the [treatment] facility school, and, in about five minutes, I was in a counselor's office enrolling. I don't think no one at the school [students] knew of my past. There are so many kids at the school, no one probably noticed me because I wasn't causing any problems.

The larger communities also seemed willing to accept Jessica, Lisa, Mick, and John. John's legal guardian gave him a party after he was released from treatment. Neighbors and family were invited to show they had missed John, and that they supported his efforts to get help. "I was kinda glad for the party. I was wondering how my next door neighbors were going to act when I got out. The party made it easier for me to fit back in. I was able to hang out with people my age without people thinking I'm trying to corrupt their son or daughter." Mick and Lisa had the same good fortune with their neighbors. People who knew of their past never mentioned it. Lisa commented, "I just didn't want a whole lot of people in my business. . . No one asked questions, even though they knew where I had been. It was not long before I was a normal teenager. I didn't have to go through any problems with friends and neighbors as the facility staff said I might." Mick had the same experience. "I knew everyone knew of my drug treatment but no one mentioned it. Friends and neighbors 
acted as if I didn't have a problem. They accepted me back as if I wasn't the boy who used to steal from them and be high and drunk all the time."

\section{Family Stress/Family Support}

As already suggested, Melinda, Anthony, and Ali had limited family support, succor that may have shielded them emotionally from a racist world. Melinda commented. "I wanted her [Mom] to come and visit so bad. I wanted her to know how I was doing, and how I was working on trying to get home. . . She came once during my stay and only stayed thirty minutes. Me and my father pleaded with her to stay, and she wouldn't." Melinda's hope was that her mother would see how well she was progressing and look forward to her daughter's return home. Melinda's step-father was only partially supportive.

Ali's family appeared to be emotionally supportive when he first arrived in treatment. They attended some group meetings. But during one group therapy session Ali's father stated, "it is uncommon for persons from Jordan to involve themselves with drugs, and Ali has shamed the family." Ali's face lowered, and after his family left, he prayed they would never return. Ali's prayer was at least partially answered because his father, two brothers, and sister did not return for some time, claiming their heavy work schedules precluded it. After Ali's release it seemed to him that his father was unable to forgive Ali for committing criminal acts and being a drug addict. And yet the older man lavished his son with expensive gifts such as a new car.

After leaving treatment, Anthony experienced a general lack of family support. When Anthony graduated from the drug treatment facility family and friends had a party celebrating his return home. Thoughtlessly, they served alcohol and drugs. His brother stated that it took some doing to get Anthony to take a drink, but his mother convinced him that he could because of the party; but she cautioned him to stop the next day.

Conversely, the families of the four recovering youngsters were involved in the participants' treatment and continued to be so after their children's graduations. Jessica's mother explained, "I come because I want to continue to learn about addiction and how I can continue to help Jessica. When I think I have all the answers, I might quit coming." And John's guardian still attends family meetings, even though John no longer participates.

With the exception of John, those still sober are attending A.A. and N.A. meetings with their parents. Mick said, "my family [members] challenge each other. $\mathrm{Me}$, my brother and both my parents are recovering. We ride to the meetings together. I'm only able to go twice a week, but the others attend a least three a week." The support and encouragement of his family being involved with A.A. makes it easier for him. "I used to get high with my brother, steal drugs from my father's 'stash,' and get drunk with my mother. Now that we're all sober I don't have anybody to get high with, plus we would all know if somebody slipped 
[relapsed]." As Lisa put it, "If we all stick together and support each other, one day at a time we'll beat this drug stuff."

\section{Spirituality}

The four who remained sober had hit a personal "bottom" and as a result they surrendered to a "higher power," something that seemed to encourage their sobriety [10-11]. Mick prayed "everyday for strength not to use again. People who don't use don't know how tough it is to stay clean. People, places, smells, and stuff remaind you of the times when you were using, and your mind makes you start thinking of using. Whenever this happens I just start praying." Lisa reiterated that "everyday you have to fight for your sobriety. Your mind makes you think you can do it one more time and quit again. You have to have something just as powerful as drugs to fight for you, and that is God. If I didn't pray everyday and believe God helps me, I know I would be using." Jessica rejoined, "no matter what situation I was in I knew I could pray, and God would help me. When I finally decided to stop I asked God to help me with my drug problem, and He did. I pray because without Him I know I would be using again and back to my old ways." John concluded, "I knew if I was to change my life permanently, I had to have a real relationship with God."

\section{CONCLUSION}

Social stress literature suggests that if the stress level of a recovering person's daily life reaches a perceived intolerable level, s/he will return to using. And this is exactly what happened to three of the participants. Conversely, positive environmental conditions (stress modifiers) enabled four of the participants to enjoy recovery. These participants became resilient, developing the capacity to survive and even thrive despite great personal tragedy. They accomplished this by being provided with and seeking out protective factors such as educational, familial, community, and spiritual support [12-16].

Interestingly John and Lisa even suffered considerable losses of their protective factors as time went on. Yet they made adjustments and survived without using. This suggests that resiliency can be internalized over time even when key external or environmental support wanes. The participants' spiritual convictions were particularly helpful during this regrouping process. They "came to believe" that some magnificent universal force loved and cared for them [9]. Hopefully, that damage done to their hearts is on the mend.

\section{APPENDIX A}

\section{Twelve Steps of Alcoholics Anonymous}

1. We admitted we were powerless over alcohol — that our lives had become unmanageable. 
2. Came to believe that a Power greater than ourselves could restore us to sanity.

3. Made a decision to turn our will and our lives over to the care of God as we understood Him.

4. Made a searching and fearless moral inventory of ourselves.

5. Admitted to God, to ourselves, and to another human being the exact nature of our wrongs.

6. Were entirely ready to have God remove all these defects of character.

7. Humbly asked Him to remove our shortcomings.

8. Made a list of all persons we had harmed and became willing to make amends to them all.

9. Made direct amends to such people wherever possible, except when to do so would injure them or others.

10. Continued to take personal inventory and when we were wrong promptly admitted it.

11. Sought through prayer and meditation to improve our conscious contact with God as we understood Him, praying only for knowledge of His will for us and the power to carry that out.

12. Having had a spiritual awakening as the result of these steps, we tried to carry this message to alcoholics who still suffer, and to practice these principles in all our affairs.

\section{REFERENCES}

1. W. DeJong, Relapse Prevention: An Emerging Technology for Promoting Long-Term Drug Abstinence, The International Journal of the Addictions, 29, pp. 681-705, 1994.

2. A. S. Friedman, N. W. Glickman, and M. R. Morrissey, Prediction to Successful Treatment Outcome by Client Characteristics and Retention in Treatment in Adolescent Drug Treatment Programs: A Large Scale Cross Validation Study, Journal of Drug Education, 6, pp. 149-16, 1986.

3. V. Johnson and R. J. Pandina, Effects of the Family Environment on Adolescent Substance Use, Delinquency, and Coping Styles, American Journal of Drug and Alcohol Abuse, 17, pp. 71-88, 1991.

4. R. A. Siegel and A. Ehrilich, Comparison of Personality Characteristics, Family Relationships, and Drug-Taking behavior in Low and High Socioeconomic Status Adolescents Who Are Drug Abusers, Adolescence, 24, pp. 925-936, 1995.

5. R. Tesch, The Contribution of a Qualitative Method: Phenomenological Research, Paper presented at the meeting of the American Research Association, New Orleans, Louisiana, 1988.

6. L. Barritt, A. Belkman, and K. Mulderij, Researching Education Practice, University of North Dakota, Center for Teaching and Learning, Grand Forks, North Dakota, 1985.

7. C. Moustakas, Phenomenological Research Methods, Sage, Thousand Oaks, California, 1994. 
8. R. Bogden and S. Biklen, Qualitative Research for Education, Allyn and Bacon, Boston, 1982.

9. N. K. Denzin, The Alcoholic Society: Addiction and Recovery of the Self, Transaction Publishers, New Brunswick, 1993.

10. H. M. Tiebout, The Ego Factors in Surrender in Alcoholism, Quarterly Journal of Studies on Alcohol, 15, pp. 610-621, 1954.

11. J. Nowinski, Substance Abuse in Adolescents and Young Adults: A Guide to Treatment. Norton and Company, New York, 1990.

12. C. S. Lindenberg, S. C. Gendrop, and H. K. Reiskin, Empirical Evidence for the Social Stress Model of Substance Abuse, Research in Nursing and Health, 16, pp. 351-362, 1993.

13. A. D. Kanner, J. C. Coyne, C. Schaefer, and R. S. Lazarus, Comparison of Two Modes of Stress Measurement: Daily Hassles and Uplifts versus Major Life Events, Journal of Behavioral Medicine, 4, pp. 1-39, 1981.

14. N. Garmezy, Stressors of Childhood, in Stress, Coping and Development in Children, N. Garmezy and M. Rutter (eds.), McGraw-Hill, New York, 1983.

15. E. E. Werner and R. S. Smith, Protective Factors and Individual Resilience, in Handbook of Early Childhood Intervention, Meisels and Shonkott (eds.), Cambridge University Press, Cambridge, 1990.

Direct Reprint requests to:

Welsey Long

Department of Educational Leadership

University of Oklahoma

Norman, OK 73019 